\title{
Het Audit Risico Model is springlevend!
}

\section{Peter Eimers}

SAMENVATTING De afgelopen jaren is er veel kritiek geweest op de toepasbaarheid in de praktijk van het audit risico model. Met de nieuwe controlestandaarden die vanaf 2005 van kracht zijn, is een hernieuwde en diepgaande invulling gegeven aan dit audit risico model. Deze controlestandaarden benadrukken dat de jaarrekeningcontrole een ingewikkeld beslissingsproces is, waarin de accountant telkens zorgvuldig professionele afwegingen moet maken en deze afwegingen ook expliciet moet documenteren. De nieuwe controlestandaarden geven concrete sturing aan de accountant hoe hij het accountantscontrolerisico kan en moet verminderen.

In deze bijdrage wordt ingegaan op recente artikelen in dit tijdschrift en wordt geïllustreerd dat het audit risico model springlevend is.

\section{Inleiding}

De accountantsprofessie mag zich de laatste jaren verheugen op een warme belangstelling van cliënten en hun stakeholders, regelgevers en toezichthouders. Telkens als er een boekhoudschandaal aan het licht komt (bijvoorbeeld Enron, WorldCom, Ahold, Parmalat), worden publiekelijk vragen gesteld over de effectiviteit van de controlewerkzaamheden van accountants, specifiek met betrekking tot het onderkennen van alle relevante risico's en het uitvoeren van voldoende controlewerkzaamheden om deze risico's tot een aanvaardbaar niveau terug te brengen. Het onderkennen van risico's in de controle en het uitvoeren van werkzaamheden

Dr. Peter W.A. Eimers RA is director bij PricewaterhouseCoopers Accountants NV, docent accountantscontrole aan de Vrije Universiteit te Amsterdam en vice-voorzitter van de Commissie Controlevraagstukken en Richtlijnen (CCR) van het Koninklijk NIVRA komt tot uitdrukking in het audit risico model. Het audit risico model beschrijft het accountantscontrolerisico (ACR) als een resultante van drie deelrisico's: het inherente risico (IR), het interne beheersingsrisico (ICR) en het detectierisico (DR). Anders geformuleerd: de kans op het afgeven van een verkeerde verklaring is de resultante van de mogelijk aanwezige inherente risico's (IR), het ontbreken van een mitigerend effect van interne beheersingsmaatregelen (ICR) en de inherente beperkingen aan het werk van de accountant (DR).

Wat terugkomt, is de vraag in hoeverre het audit risico model - ondanks de algemeen aanvaarde conceptuele zuiverheid - werkelijk toepasbaar is in de praktijk. Deze vraag wordt gesteld door toezichthouders, onderzoekers in binnen- en buitenland en komt tot uiting in de door de International Federation of Accountants (IFAC) uitgegeven internationale beroepstandaarden. Zo publiceerde de Amerikaanse Public Oversight Board bijvoorbeeld in 2000 een rapport over de effectiviteit van het controleproces (Panel on Audit Effectiveness, POAE, 2000). In detail heeft het panel gekeken naar de toepassing van het audit risico model en concludeerde dat '... the audit risk model is appropriate, but needs enhancing and updating' (POAE 2000, section 2.14). Blokdijk (2001) stelt mede naar aanleiding van deze publicatie dat het audit risico model zoals neergelegd in de regelgeving van de IFAC, geen deugdelijke grondslag levert voor de accountantsverklaring. Hij doelt hierbij met name op het gebrek aan effectiviteit van de toetsing van de werking van de interne controle, wat volgens Blokdijk feitelijk neerkomt op de selectie van gegevensgerichte werkzaamheden. De Koning (2002) breekt daarentegen weer een lans voor het uitvoeren van een systeemgerichte controleaanpak.

Ook onderzoekers op het gebied van accountantscontrole hebben ondanks herhaalde pogingen niet eenduidig kunnen aantonen dat accountants in hun controle effectief inspelen op veranderende risico's bij 
hun cliënten, hetgeen suggereert dat accountants het audit risico model in de praktijk niet goed toepassen. Elder en Allen (2003) vonden bijvoorbeeld wel een relatie tussen onderkende inherente risico's en omvang van gegevensgerichte werkzaamheden, maar geen relatie tussen interne beheersingsrisico's en deze werkzaamheden. Mock en Wright (1999) konden voor beide soorten risico's geen relatie vinden met de door de accountant uitgevoerde werkzaamheden. Johnstone en Bedard (2001) vonden vervolgens geen relatie tussen risicofactoren en de benodigde tijd op een opdracht, maar wel een relatie met de inzet van specialisten als respons op de specifieke risico's.

In de afgelopen jaren is - aangespoord door de aanbevelingen van het Panel on Audit Effectiveness - door de regelgevers en de praktijk hard gewerkt om het audit risico model naar de volgende ronde te brengen. Deze inspanningen hebben geleid tot de nieuwe en ingrijpend veranderde internationale controlestandaarden van IFAC die vanaf 2005 van kracht zijn. Het audit risico model staat nu fysiek waar het hoort: als conceptueel raamwerk in Richtlijn voor Accountantscontrole (RAC) 200. Nieuwe en aangepaste standaarden (o.a. RACs $315,330,500$ ) geven concrete invulling aan dit fundament voor het controleproces. Een vergelijkbare ontwikkeling heeft zich in de Verenigde Staten voorgedaan waar de Public Company Accounting Oversight Board (PCAOB) de relevantie van het audit risico model voor de praktijk onderstreept met het adopteren van het audit risico model in de auditstandaarden (PCAOB, 2004) en het benadrukken van importantie van de beheersingsomgeving (PCAOB, 2005).

In deze bijdrage analyseer ik de onderkende probleempunten in het audit risico model (paragraaf 2) en op welke wijze deze probleempunten zijn ondervangen met de komst van de Richtlijnen ${ }^{1}$ voor de Accountantscontrole 2005 (NIVRA 2005a, verder 'RAC 2005 ') in paragraaf 3 , gevolgd door een conclusie in paragraaf 4 .

\section{Analyse van onderkende probleempunten}

\subsection{Inherent risico versus interne beheersing}

Het onderkennen van de interactie tussen onderkende risico's en de maatregelen van interne beheersing is cruciaal voor een effectieve en efficiënte controle: enerzijds kan het niet onderkennen van bepaalde risico's door de cliënt en/of de accountant leiden tot het aanwezig blijven van een fout in de jaarrekening, anderzijds kan het beoordelen van interne beheersingsmaat- regelen zonder de link te leggen met de achterliggende risico's leiden tot controlewerkzaamheden die niets toevoegen. In de vorige uitgave van de RAC (RAC, editie 2002) was in RAC 400 om die reden een tabel opgenomen, waaruit bleek dat een laag geschat inherent risico in combinatie met een laag geschat interne beheersingsrisico leidde tot een gemiddeld ontdekkingsrisico. In de praktijk hadden velen moeite om concreet aan te geven wat 'gemiddeld ontdekkingsrisico' betekende voor de werkzaamheden voor de accountant. Naar mijn mening heeft het weinig zin om naar inherente risico's te kijken zonder de mitigerende maatregelen van interne beheersing daarbij te betrekken. Laten we twee ondernemingen vergelijken: een internationale bank en een plaatselijk handelsbedrijf. Welke onderneming heeft de grootste inherente risico's? Veronderstel de bank, omdat daar geen aanknopingspunten zijn uit een geld-goederenbeweging. Welke onderneming heeft het laagste interne beheersingsrisico? Veronderstel de bank, omdat de bank de grootste schade kan ondervinden van niet adequaat werkende maatregelen van interne beheersing. Tot zover niets nieuws. Maar wat betekent de combinatie van deze feiten voor de werkzaamheden van de accountant?

Knechel (2001) maakte onderscheid tussen businessrisico en procesrisico als invulling van de eerder genoemde risicobegrippen waarbij hij per onderkend risico een respons van de accountant verwachtte. Met dit onderscheid - risico's van buiten en van binnen de onderneming - wordt aansluiting gevonden met de praktijk. Een niet-werkend computersysteem bijvoorbeeld is een procesrisico en daar kun je als accountant concreet actie op ondernemen in de controle, voor zover er geen sprake is van een onvervangbare maatregel van interne beheersing. Een ander hardnekkig issue in de praktijk is het vertalen van onderkende risico's in concrete controlewerkzaamheden: zodra de risico's door de accountant zijn onderkend, welke beheersing hoort daarbij en hoe moet dat worden getoetst (opzet, bestaan en effectieve werking)? Moet je het interne beheersingsrisico toepassen op het gehele stelsel van interne beheersing ('hoog, middel, laag risico'), of ten aanzien van een specifieke beheersingsmaatregel?

\subsection{Systeemgericht versus gegevensgericht}

Een terugkerend thema in de literatuur is de kritische houding ten aanzien van de waarde van systeemgerichte controlewerkzaamheden, die inhouden dat de accountant toetst of de interne beheersingsmaatregelen effectief werken. Blokdijk (2001) stelt dat bij het ontbreken van een goede testmogelijkheid van de 
interne beheersing de te verrichten werkzaamheden veel beter rechtstreeks kunnen worden gericht op de selectie van gegevensgericht te onderzoeken posten. Kloosterman (2004) suggereert dat systeemgerichte werkzaamheden slechts zijn bedoeld om met grote stappen snel thuis te komen ('auditors willen met zo weinig mogelijk werk tot een zo hoog mogelijke opbrengst komen'). Afgezien van het feit dat dit een normaal economisch begrip is, is deze stelling opmerkelijk in het huidige tijdsbeeld waarin accountants juist kritiek krijgen dat zij te streng zouden zijn (PCAOB, 2005). Accountants zullen steeds minder geneigd zijn te weinig te doen, mede gezien de mogelijke repercussies door toezichthouders. Uiteraard zal de accountant naar een efficiënte audit streven, zolang dat maar niet ten koste gaat van de effectiviteit.

De tegenpool van een systeemgerichte aanpak is de gegevensgerichte aanpak die bestaat uit gegevensgerichte cijferanalyses en detailcontroles van transactiestromen, jaarrekeningposten en onderdelen van de toelichting. Binnen deze aanpak komt ook de wiskundige benadering van risicoanalyse van tijd tot tijd om de hoek kijken (recentelijk weer Kloosterman, 2004). Uiteraard kunnen wiskundige en statistische uitingen als de toepassing van steekproeven en audit software een rol spelen in de audit, maar dat is niet bepalend voor het audit proces. Voordat deze middelen kunnen worden ingezet, is eerst een grondige risicoanalyse noodzakelijk om de audit strategie te bepalen. Je kunt bij wijze van spreken gegevensgerichte werkzaamheden uitvoeren tot aan de laatste inkoopfactuur, als je niet hebt gezien dat de directie kan ingrijpen in de boekingsgang, dan is de controleaanpak mogelijk niet effectief geweest.

In de afgelopen decennia is de discussie ontstaan of het audit risico model gezien moet worden als het wiskundige model $\mathrm{ACR}=\mathrm{IR}^{\star} \mathrm{ICR}^{\star} \mathrm{DR}$ of als het conceptueel model ACR $=$ f(IR, ICR, DR). Schilder (1991) wist de discussie over de juiste interpretatie - met de prikkelende titel 'rekenmodel, denkmodel of wedstrijdmodel' - van het audit risico model terug te brengen tot de kern: je moet begrijpen wat er conceptueel met het model wordt bedoeld en je moet nagaan wat de consequentie hiervan is voor de uitvoering van de controlewerkzaamheden.

\subsection{Ruimere toepassing}

Mollema (2003) concludeert dat het audit risico model is toegesneden op de controle van de jaarrekening en minder toepasbaar is voor andere vormen van audit. Een van de redenen die hij aangeeft, is dat gegevens- gerichte werkzaamheden (zoals een guldensteekproef) niet toepasbaar zijn op de controle van nietfinanciële informatie. Het audit risico model is naar mijn idee echter generiek en toepasbaar in allerlei contexten. Te denken valt bijvoorbeeld aan een assurance opdracht waarin een uitspraak wordt gedaan over de opzet, bestaan en werking van een proces van interne beheersing. De overeenkomst tussen een jaarrekeningcontrole en een assuranceopdracht die is gericht op een proces, is dat er in beide opdrachten inherente risico's, interne beheersingsrisico's en detectierisico's aanwezig zijn. Het kenmerkende verschil met een jaarrekeningcontrole is dat bij een assuranceopdracht die gericht is op een proces tekortkomingen in het systeem van interne beheersing niet kunnen worden gecompenseerd door gegevensgerichte werkzaamheden van de accountant omdat de accountant een uitspraak wil doen over de effectieve werking van het proces en niet over de uitkomst. Het detectierisico heeft bij deze laatste opdracht dus niet betrekking op het ontoereikend uitvoeren van gegevensgerichte werkzaamheden. Hiermee wil ik benadrukken dat het gaat om de conceptuele toepassing van het audit risico model en niet om de concrete invulling met controlemiddelen; al naar gelang de aard van de opdracht zal de accountant andere controlemiddelen uit zijn gereedschapskist gebruiken.

\section{RAC 2005: Een nieuwe invulling van het audit risico model}

\subsection{Inleiding: De rode draad}

Risicoanalyse en de daaruit volgende werkzaamheden komen in een aantal belangrijke en vernieuwde standaarden ${ }^{2}$ aan de orde: RAC 200 ('Doel en algemene uitgangspunten van de controle van een jaarrekening', RAC 240 ('Fraude'), de RAC 300 serie ('Risicoinschatting en het inspelen op ingeschatte risico's', waaronder $^{3}$ RAC 300, RAC 315 en RAC 330) en RAC 500 ('Controle-informatie'). Centraal in de nieuwe RACs $240,315,330$ en vernieuwde RAC 500 staat 'the story of the audit', namelijk het proces van het identificeren van risico's en de respons op deze risico's om uiteindelijk te kunnen concluderen in hoeverre de jaarrekening een getrouw beeld geeft. Het controleproces is niet een mechanische exercitie, maar een dynamisch en iteratief denkproces waarin bij onvoldoende diepgang en zorgvuldigheid van alles mis kan gaan. Een ontoereikende uitvoering van dit proces kan uiteindelijk leiden tot het ten onrechte afgeven van een goedkeurende accountantsverklaring. Zo kun je als accountant een of meerdere risico's missen 
Figuur 1: Hoofdlijnen van de moderne risicoanalyse

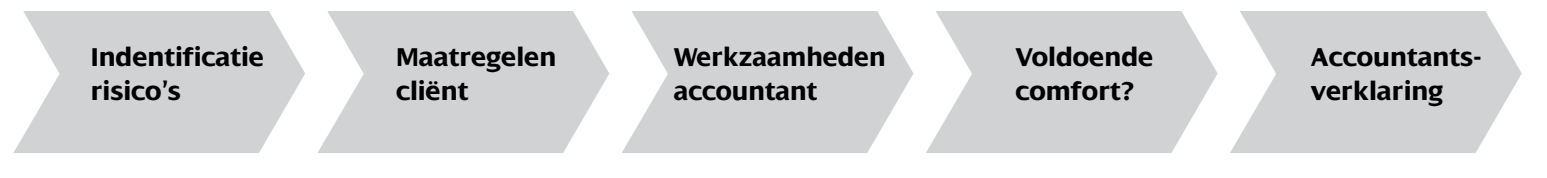

in de risicoanalyse of kun je na de identificatie van risico's fouten maken in de analyse van de beheersingsmaatregelen van de cliënt of in de uitvoering van gegevensgerichte werkzaamheden.

De hoofdlijnen van een moderne risicoanalyse kunnen als volgt worden samengevat:

a identificatie van risico's (RAC 315, 240);

b maatregelen van de cliënt om de risico's te mitigeren (RAC 330, 240);

C werkzaamheden van de accountant: verzamelen van controle-informatie (RAC 330, 500), zowel systeemgerichte als gegevensgerichte elementen;

\footnotetext{
Deze nieuwe controlestandaarden kenmerken zich door:

- het centraal stellen van professionele oordeelsvorming:

accountantscontrole is geen mechanische exercitie, maar een

vakkundig beslissingsproces;

- het benadrukken van kennisuitwisseling in het team: cruciaal

voor goede risicoanalyse en respons. Met elkaar weet je meer;

- meer aandacht voor de ruimere omgevingsrisico's ('business risks') als startpunt voor de controle;

- een expliciete link tussen het door de accountant identificeren van risico's en de respons van de accountant. De keuze tussen systeemgerichte of gegevensgerichte controleaanpak is niet relevant. Het gaat om de rode draad tussen onderkende risico's, de interne beheersingsmaatregel om het risico te mitigeren en de door de accountant uit te voeren effectieve en efficiënte mix van controlemiddelen;

- de toepassing van risicoanalyse op zowel het niveau van de jaarrekening als geheel als op het niveau van de daarin opgenomen transactiestromen, jaarrekeningposten en toelichtingen;

- de beperking van de keuze tussen systeem- versus gegevensgericht: bij een significant risico dient de accountant minimaal de opzet en het bestaan van de mitigerende beheersingsmaatregel te toetsen;

- het expliciet maken van de noodzaak van het testen van de werking van aanwezige interne beheersingsmaatregelen als daarop wordt gesteund. Het 'vertrouwen' op een goede werking kan niet;

- het onder de aandacht brengen van de expliciete afweging of de uitgevoerde werkzaamheden voldoende comfort hebben gegeven en eventuele aanvullende werkzaamheden uit te voeren; - het opnemen van de verplichting tot grondige documentatie rond het beslissingsproces.
}

d evaluatie: genoeg comfort? (RAC 330, 500); e afgeven accountantsverklaring (RAC 700).

\subsection{Het fundament: RAC 200}

De rode draad van risicoanalyse start met RAC 200 waarin de uitgangspunten van de controle worden aangegeven. Net als voorheen is het doel van de controle van een jaarrekening een oordeel te geven of de jaarrekening in alle van materieel belang ${ }^{4}$ zijnde opzichten in overeenstemming is met de van toepassing zijnde grondslagen van financiële verslaggeving (200.2). Dat doet de accountant door zijn werkzaamheden zodanig te plannen en uit te voeren dat het accountantscontrolerisico wordt gereduceerd tot een aanvaardbaar laag niveau dat overeenkomt met de doelstelling van de accountantscontrole (200.15). Anders dan voorheen wordt het accountantscontrolerisico, door het samen nemen van het inherente en interne beheersingsrisico, gepositioneerd als een functie van twee typen risico's, te weten:

- het risico dat de jaarrekening voorafgaande aan de accountantscontrole een afwijking van materieel belang bevat (of kortweg, het 'risico van een afwijking van materieel belang');

- het risico dat de accountant een dergelijke afwijking niet zal ontdekken (het 'ontdekkingsrisico').

Het inherente risico en het interne beheersingsrisico zijn risico's van de huishouding bij het opmaken van de jaarrekening; slechts de resultante van deze twee risico's is van belang voor de accountant bij de controle van de jaarrekening. Van de accountant wordt vereist dat hij een inschatting maakt van het risico van een afwijking van materieel belang op beweringniveau ${ }^{5}$ als ook op totaalniveau van de jaarrekening. Het verschil tussen beide niveaus komt tot uiting in de gevolgen van deze risico's. Het risico dat de voorraad niet bestaat ('bestaan' is een bewering) is van een andere gradatie dan het risico op ingrijpen in de boekingsgang bij de jaarafsluiting door het management (dat is een risico dat boven de hele jaarrekening hangt). De inschatting op beweringniveau kan beperkt blijven tot een inschatting en hoeft niet te bestaan uit de exacte 
bepaling van het risico. De RAC 2005 gaat ervan uit dat de accountant een gecombineerde inschatting maakt van het risico van een afwijking van materieel belang, al kan de accountant nog steeds afzonderlijke of deels gecombineerde inschattingen maken van het inherente risico en het interne beheersingsrisico, afhankelijk van zijn voorkeur voor bepaalde controletechnieken of -methoden en praktische overwegingen.

De accountant beoordeelt het risico van een afwijking van materieel belang op het totaalniveau van de jaarrekening. Daarbij gaat het om het risico van een afwijking van materieel belang dat nauw verweven is met de jaarrekening als geheel en dat mogelijk een groot aantal beweringen beïnvloedt. Dergelijke risico's hebben vaak betrekking op de business of de beheersingsomgeving van de huishouding ('totaalrisico') en zijn niet noodzakelijkerwijs direct gekoppeld aan bepaalde beweringen op het niveau van transactiestromen, jaarrekeningposten of toelichting. Uiteindelijk moeten deze risico's wel worden doorvertaald naar de consequenties voor de jaarrekeningposten. Dit totaalrisico slaat meer op de omstandigheden die het risico verhogen van een afwijking van materieel belang en die doorwerken in een antal verschillende beweringen, bijvoorbeeld het doorbreken van de interne beheersingsmaatregelen door de leiding van de huishouding. Dergelijke risico's komen met name in beeld bij de beoordeling door de accountant van het risico van een afwijking van materieel belang ten gevolge van fraude. Het inspelen door de accountant op het ingeschatte risico van een materiële afwijking op het totaalniveau van de jaarrekening omvat onder meer:

- een beoordeling van de kennis, ervaring en deskundigheid van belangrijke leden van het controleteam;

- de vraag of deskundigen moeten worden ingeschakeld;

- of er juiste niveaus van supervisie in het team zijn; en

- of er gebeurtenissen of omstandigheden zijn die een aanwijzing vormen voor belangrijke twijfels omtrent de mogelijkheden van de huishouding tot voortzetting van de bedrijfsactiviteiten.

De accountant beoordeelt tevens het risico van een afwijking van materieel belang op het niveau van transactiestromen, jaarrekeningposten en toelichting. Deze beoordeling biedt direct ondersteuning bij het bepalen van de aard, tijdsfasering en omvang van de verdere controlewerkzaamheden op beweringniveau. Deaccountant tracht op een zodanige wijze toereikende controleinformatie te verkrijgen op het niveau van transactiestromen, jaarrekeningposten en toelichtingen dat deze hem op het moment van afronding van zijn controle in staat stelt een oordeel te formuleren over de jaarreke- ning als geheel met een aanvaardbaar laag accountantscontrolerisico. Accountants kunnen verschillende benaderingen hanteren om deze doelstelling te bereiken ${ }^{6}$.

\subsection{RAC 315: Identificatie van risico's is cruciaal}

Bij het identificeren van risico's kan de accountant vele risico's onderkennen, die waarschijnlijk niet alle dezelfde impact zullen hebben. RAC 315 introduceert daarom de term 'belangrijk risico' ter onderscheiding van overige risico's. Een belangrijk (dus significant) ${ }^{7}$ risico kan worden gedefinieerd als 'een risico of factor die een verhoogde kans geeft op een materiële fout'. Populair gezegd: een significant risico is een risico waar de cliënt van wakker zou kunnen of moeten liggen. Als de accountant een significant risico onderkent, dan zal hij altijd de opzet en het bestaan van de mogelijke mitigerende interne beheersingsmaatregelen moeten doorgronden en documenteren, ook al steunt de accountant in zijn controle niet op deze beheersingsmaatregel. Op zich is het logisch: als accountant moet je willen weten of er een beheersingsmechanisme in het bedrijf is dat het significante risico afdoende mitigeert. Is dat laatste niet het geval, dan is die observatie een onderwerp voor het accountantsverslag.

Het onderscheid tussen significante risico's en overige risico's blijkt in de praktijk ingewikkelder dan het op het eerste gezicht lijkt. Niet elke materiële balanspost leidt tot een significant risico. Niet een post in de jaarrekening zelf, maar een factor die tot het verhoogde risico op een materiële fout leidt, is hierbij van belang. De Parmalat-casus laat zien dat een zeer materiële, doch eenvoudig te controleren post als liquide middelen gerelateerd kan zijn aan een significant risico. Niet het saldo is bepalend, maar het frauderisico door het feit dat $€ 4$ miljard op een bankrekening zou staan op een ver eiland terwijl in Italië crediteuren steeds langer op hun geld moesten wachten. Kennis van de klant en omgeving is dus een cruciale randvoorwaarde voor het uitvoeren van de risicoanalyse. Een significant risico voor onderneming $\mathrm{X}$ hoeft overigens niet een significant risico te zijn voor onderneming $\mathrm{Y}$ in dezelfde branche, als de accountant op voorhand weet dat onderneming $\mathrm{Y}$ goede maatregelen van interne beheersing op dat gebied heeft. Dat wil niet zeggen dat de accountant geen werkzaamheden gaat verrichten aan het risico bij Y: hij weegt af of hij gaat steunen op de beheersingsmaatregel(en) (dus systeemgericht) of dat hij daaraan voorbijgaat en zelf - voor zover er geen sprake is van een onvervangbare maatregel van interne beheersing - gegevensgericht aan de slag gaat. 
Voordat de accountant kan overgaan tot het identificeren van risico's zal hij kennis van de cliënt en de bedrijfstak moeten vergaren. Deze grondige omgevingsanalyse (Gortemaker en Wallage, 2003) heeft als functie om zo volledig mogelijk te zijn in het onderkennen van het aantal mogelijke risico's op materiële onjuistheden in de jaarrekening. Deze analyse staat dus niet op zich, maar heeft een cruciale functie in de risicoanalyse.

\subsection{Interne beheersing}

Nieuw in RAC 315 is ook dat de accountant expliciet moet doorgronden hoe de interne beheersingsomgeving werkt, waarbij de 5 componenten van $\mathrm{COSO}^{8}$ als uitgangspunt gelden:

- de beheersingsomgeving;

- het risico-inschattingsproces van de huishouding;

- interne beheersingsactiviteiten (op applicatieniveau);

- het informatiesysteem;

- toezicht op de werking van de beheersingsmaatregelen.

De diepgang waarmee de accountant deze interne beheersingsomgeving benadert, is afhankelijk van de complexiteit van de bedrijfsprocessen en de mate waarin de accountant gebruik wil gaan maken van de maatregelen van interne beheersing. Ook al wil de accountant voornamelijk gegevensgerichte werkzaamheden uitvoeren, hij zal toch minstens aandacht moeten besteden aan de wijze waarop het management de onderneming aanstuurt (beheersingsomgeving, frauderisico) en op welke wijze het management in staat is de significante risico's te mitigeren.

Bij veel ondernemingen speelt informatietechnologie een belangrijke rol. De accountant zal dan ook bij elke controleopdracht moeten nagaan welke risico's er verbonden zijn aan het geautomatiseerde informatieverzorgingsysteem en zal hij passende controlewerkzaamheden moeten uitvoeren om deze risico's tot een anvaardbaar niveau te reduceren. Zelfs bij relatief 'eenvoudige' systemen zal de accountant zich moeten afvragen op welke wijze de uit het systeem gegenereerde overzichten voldoende basis vormen voor gebruik in de audit.

\subsection{Frauderisico}

Ook de fraudestandaard (RAC 240) is met ingang van 2005 aanzienlijk uitgebreid en aangescherpt. Uitgangspunt is nog steeds dat de accountant geen fraudeofficier of opsporingsambtenaar is. Wel wordt een duidelijke link gelegd met de risicoanalyse uit RAC
315 , omdat de accountant geacht wordt met een hoge mate van zekerheid de materiële onjuistheden in de jaarrekening te identificeren, of deze onjuistheden nu onbewust (fouten) of bewust (fraude) worden begaan. Hij heeft dus een actieve onderzoeksplicht met betrekking tot het identificeren van risico's op materiële fraudes en kan niet passief afwachten totdat hij (toevallig) op een vermoeden van fraude stuit.

Controleteams zijn verplicht om in de planningsfase de kennis over deze frauderisico's te delen en de confrontatie aan te gaan met management en toezichthoudende organen over hun inschatting van het frauderisico en de getroffen maatregelen van interne beheersing. Is een frauderisico onderkend, dan kwalificeert dit als een significant risico, omdat de accountant op basis van RAC 240 verplicht is om na te gaan hoe het management het frauderisico mitigeert met maatregelen van interne beheersing. Onderscheid wordt overigens gemaakt tussen twee soorten fraude: verduisteren van bezittingen en frauduleuze rapportering. Met name deze laatste categorie legt de vinger op de zere plek gezien de beursschandalen van de afgelopen paar jaar: prikkels van management in beloningscontext kunnen leiden tot een verhoogd risico op het schuiven met resultaten. Een niet onbelangrijk element in de controlewerkzaamheden met betrekking tot fraude is het inbouwen van onvoorspelbaarheid in de controlewerkzaamheden. Was de Nederlandse accountant al opgegroeid met 'op overvalmomenten de kas opnemen', nu is hij bij elke controleopdracht verplicht om enige onvoorspelbaarheid in zijn controlewerkzaamheden in te bouwen. Dit kan de accountant bijvoorbeeld doen door op andere tijdstippen en onaangekondigd te controleren, gebruik te maken van alternatieve selectiemethoden en/of gegevensgerichte werkzaamheden uit te voeren voor posten die op zich niet materieel zijn. Met deze onvoorspelbaarheid verkleint de accountant het risico dat een kwaadwillende cliënt anticipeert op bekende jaarlijks terugkerende controlewerkzaamheden.

\subsection{RAC 330: Respons op geïdentificeerde risico's}

Nieuw in de controlestandaarden is ook de verplichting om de door de accountant onderkende risico's en zijn respons per materiële jaarrekeningpost en per controledoelstelling te documenteren, om vervolgens expliciet te concluderen dat elk onderkend risico aan het einde van de controle is afgedekt. Met deze nieuwe documentatieverplichting wordt onder meer bereikt dat de link tussen interim-controle en jaareindecon- 
trole veel duidelijker zichtbaar wordt; hiermee worden zowel de effectiviteit als de efficiency van het controleproces bevorderd.

Voor zover de accountant gebruik wil maken van een maatregel van interne beheersing, zal hij gefundeerd moeten toetsen of hij daadwerkelijk kan steunen op deze maatregel. Ja of nee. Een beetje steunen is niet voldoende. Door deze scherpere eis ten aanzien van de evaluatie of de interne beheersingsmaatregelen toereikend zijn - ook ten aanzien van documentatie -, zal de accountant mogelijk eerder dan voorheen concluderen dat hij niet kan steunen op deze maatregelen en zal hij direct overgaan tot gegevensgerichte werkzaamheden. Anderzijds stimuleren de nieuwe standaarden de accountant om meer gebruik te maken van de aanwezige maatregelen van interne beheersing, zolang hij de opzet, bestaan en werking maar intensief toetst. Betreft het een significante balans- of resultatenrekeningpost, dan zal de accountant naast de systeemgerichte toets altijd aanvullend een gegevensgerichte toets moeten uitvoeren. Hieronder vallen onder andere cijferanalyses, waarneming ter plaatse, versturen van confirmaties, (statistische en niet-statistische) steekproeven en kritische deelwaarneming. Data-analyse tools geven in toenemende mate de accountant de mogelijkheid om op steeds eenvoudiger wijze door computerbestanden heen te lopen. Gegevensgerichte werkzaamheden in aanvulling op de systeemgerichte werkzaamheden accentueren de toegevoegde waarde om beide typen werkzaamheden te combineren. Dat geldt ook in omgekeerde situaties: een geheel gegevensgerichte aanpak zal niet toereikend zijn. Veel cliëntsituaties zijn complex en daardoor kunnen controles niet met louter gegevensgerichte werkzaamheden worden uitgevoerd. Er zijn altijd maatregelen van interne beheersing die in ogenschouw moeten worden genomen (zoals de controleomgeving, veelal de IT-omgeving en ook de beheersing van het frauderisico).

\subsection{Documentatievereisten}

Met de komst van nieuwe controlestandaarden zijn er nieuwe gedetailleerdere documentatievereisten die in elke nieuwe standaard specifiek worden benoemd. Deze vereisten komen één op één voort uit de werkzaamheden die eerder in deze bijdrage zijn genoemd. De accountant dient namelijk datgene vast te leggen wat belangrijk is voor de onderbouwing van het verstrekte accountantsoordeel en voor het aantonen dat de controle is verricht in overeenstemming met in Nederland algemeen aanvaarde controlegrondslagen.
Uit de externe kwaliteitstoetsingen die zijn uitgevoerd door het College Toetsing Kwaliteit (NIVRA, 2005b) blijkt dat accountants in een aantal gevallen onvoldoende de rode draad van het controleproces ('the story of the audit') vastleggen in het dossier. Ondanks de aangescherpte regels blijft de basis van dossiervorming hetzelfde: het is een weerslag van 'the story of the audit' (Eimers, 2005). Het adagium van toezichthouders 'niet gedocumenteerd is niet gecontroleerd' krijgt met deze documentatievereisten in de nieuwe onderdelen van de RAC 2005 zijn weerslag.

\section{Conclusie: Oude wijn in nieuwe zakken?}

De nieuwe controlestandaarden bieden de noodzakelijke verdieping van het conceptuele model en beantwoorden de belangrijkste punten van kritiek die vanuit de literatuur, toezichthouders en praktijk leefden. De nieuwe standaarden weerspiegelen een zorgvuldig beslissingsproces dat de accountant doorloopt tijdens zijn controleopdracht. Wie dit beslissingsproces tot in de puntjes beheerste, lijkt op het eerste gezicht in de nieuwe standaarden niet veel nieuws tegen te komen. Inderdaad is het beslissingsproces niet anders dan in het verleden: het audit risico model bestaat immers al jaren. Belangrijk verschil met het verleden is echter dat een concrete invulling wordt gegeven aan het audit risico model waarin de sterk complexer geworden cliënt- en stakeholdersomgeving van de afgelopen jaren haar weerslag heeft gevonden. In een dergelijke aanpak is het geen zwart-witkeuze tussen gegevensgericht of systeemgericht: op basis van de onderkende risico's bepaalt de accountant een mix van controlemaatregelen die effectief en efficiënt het audit risico tot een aanvaardbaar niveau terugbrengen.

Daarnaast zorgen strengere documentatievereisten ervoor dat de accountant zijn afwegingsproces meer dan in het verleden moet documenteren. Externe toezichthouders zullen de accountant hieraan zonodig herinneren. Enige waakzaamheid is wel geboden: het toepassen van de nieuwe huisregels 'omdat het moet' leidt niet tot een goede audit. De basis blijft hetzelfde: professional judgement was, is en blijft cruciaal. Vanaf 2005 wel met inachtneming van de nieuwe huisregels. Het audit risico model: springlevend!

\section{Literatuur}

\footnotetext{
Blokdijk, J.H. (2001), De effectiviteit van de systeemgerichte aanpak in de accountantscontrole, in: Maandblad voor Accountancy en Bedrijfseconomie, 75e jaargang nr. 3, maart, pp. 71-80.

Blokdijk, J.H. (2002), De toetsing van de werking van de interne controle, in: Maandblad voor Accountancy en Bedrijfseconomie, 76e jaargang nr. 12,
} 
december, pp 613-615.

Elder, R.J. en R.D. Allen (2003), A longitudinal field investigation of auditor risk assessments and sample size decisions, in: The Accounting Review, vol. 78, No. 4, pp. 983-1002.

Eimers, P.W.A. (2005), 'The story of the audit': documentatievereisten in de 21e eeuw, in: Handboek Accountancy, Supplement 7(september), pp. 1-20.

Gortemaker, J.C.A. en Ph. Wallage (2003), Accountantscontrole gebaseerd op bedrijfsrisico's, in: Handboek Accountancy, 77e jaargang, juni, A 4040 $-1 / 16$.

Johnstone, K.M. en J.C. Bedard (2001), Engagement planning, bid pricing, and client response in the market for initial attest engagements, in: The Accounting Review, Vol. 76, No. 2, pp. 199-220.

Kloosterman, H. (2004), Wat is eigenlijk risicoanalyse in de accountantscontrole?, in: Maandblad voor Accountancy en Bedrijfseconomie, 78e jaargang, nr. 12, december, pp. 570-578.

Knechel, R. (2001), Auditing: Assurance \& Risk, 2nd edition, Southwestern College Publishing, Cincinnati.

Koning, F. de, (2001), Beoordeling van de interne controle in het kader van de accountantscontrole, in: Maandblad voor Accountancy en Bedrijfseconomie, 76e jaargang, nr. 6, juni, pp. 272- 280.

Koninklijk Nederlands Instituut voor Registeraccountants (NIVRA) (2005a), Richtlijnen voor de Accountantscontrole, editie juni 2005.

Koninklijk Nederlands Instituut voor Registeraccountants (NIVRA) (2005b), Jaarverslag College Toetsing Kwaliteit, 2004/2005.

Mock, T.J., en A.M. Wright (1999), Are Audit Program Plans Risk-Adjusted?, in: Auditing: A Journal of Practice and Theory, Vol. 18, No. 1, pp. 55-74.

Mollema, K. (2003), Auditrisico, meer dan ooit een issue! (1), in: Maandblad voor Accountancy en Bedrijfseconomie, 77e jaargang, nr. 12, december, pp. 551-556.

Mollema, K. (2004), Auditrisico, meer dan ooit een issue! (2), in: Maandblad voor Accountancy en Bedrijfseconomie, 78e jaargang, nr. 1/2, januari/februari, pp. 5-15.

Public Company Accounting Oversight Board (2004), Auditing Standard 2 An audit of Internal Control over Financial Reporting Performed in Conjunction with An audit of Financial Statements.

Public Company Accounting Oversight Board (2005), PCAOB Issues Guidance on Audits of Internal Control, press release 16 May.

Public Oversight Board (POB) (2000), The Panel On Audit Effectiveness, report and recommendations.

Schilder, A. (1991), Risicoanalyse: rekenmodel, denkmodel of wedstrijdmodel? Een nabeschouwing van een boeiend debat, in: De Accountant, 97e jaargang, mei, pp. 573-576.

\section{Noten}

1 Nederland is bekend met de Richtlijnen voor de Accountantscontrole (RAC). Door de verwevenheid met de internationale vereisten die zijn opgenomen in de International Standards on Auditing (ISA), hebben deze richtlijnen inmiddels het karakter gekregen van standaarden.

2 Vervallen zijn de RAC 310, 400 en 401. De inhoud van deze standaarden is verweven in RAC 200, 315 en 330. De in paragraaf 2 vermelde tabel bij RAC 400 is niet meer opgenomen in de RAC 2005.

3 Hiertoe behoort ook RAC 320 ('Materieel belang in de accountants- controle'), die nog niet is aangepast in afwachting van besluitvorming bij de International Auditing and Assurance Standards Board. (IAASB), het orgaan van IFAC dat is belast met de vaststelling van assurance standaarden. In deze bijdrage wordt niet nader ingegaan op RAC 320.

4 Informatie is materieel indien het weglaten of het onjuist weergeven daarvan de economische beslissingen die gebruikers op basis van de jaarrekening nemen, zouden kunnen beïnvloeden. De materialiteit van de post of fout is afhankelijk van de omvang daarvan, beoordeeld onder de specifieke omstandigheden waaronder het weglaten of onjuist weergeven plaatsvindt. Het begrip materialiteit verschaft dus meer een drempel of kritische grens, dan dat het een primair kwalitatief kenmerk is dat informatie moet bezitten om nuttig te zijn (RAC 320 paragraaf 3).

5 'Bewering' als vertaling van 'assertion'. In Nederland meer bekend als 'getrouwheidsaspect' of 'controledoelstelling'.

6 Voetnoot 6 van RAC 200 houdt een opening voor het wiskundig benaderen van het audit risicomodel, maar voegt er aan toe dat '...een dergelijk model de oordeelsvorming die bij het accountantscontroleproces hoort niet overbodig maakt.'

7 ISA 315 spreekt van 'significant risk'; in RAC 315 is dit vertaald met 'belangrijk risico'. In deze bijdrage wordt gesproken over 'significant risico', omdat deze benaming meer onderscheidend is van overige risico's.

8 In 1992 publiceerde het Committee of Sponsoring Organizations of the Treadway Commission het rapport Internal Control: Integrated Framework. ('COSO'). COSO verzocht het toenmalige accountantskantoor Coopers \& Lybrand een voorstel te ontwikkelen om het begrip interne beheersing hanteerbaarder te maken. IAASB heeft het COSO model als uitgangspunt genomen. Pas nadat ISA 315 door IAASB was goedgekeurd, werd de opvolger COSO ERM ('Enterprise Risk Management') uitgebracht met daarin 8 interne beheersingselementen. Aangezien de nieuwe elementen een nadere uitwerking zijn van de eerdere versie van Coso, kan naar mijn mening ook COSO ERM worden toegepast ter invulling van ISA/RAC 315. 